\title{
IDENTIFYING PSYCHOLOGICAL SUBJECT AS A THEME: FOCUSING ON ENGLISH DECLARATIVE CLAUSES
}

\begin{tabular}{|c|c|}
\hline \multicolumn{2}{|c|}{$\begin{array}{l}\text { Puspita Sari }{ }^{1} \text {, Diana Anggraeni }{ }^{2} \\
{ }^{1} \text { English Department of Faculty of Languages- Bandung Widyatama University } \\
\text { }{ }^{2} \text { English Literature of Social and Political Science- Bangka Belitung University } \\
\text { Corresponding Author: Puspita Sari, Email: puspita.sari@widyatama.ac.id }\end{array}$} \\
\hline ARTICLE INFO & ABSTRACT \\
\hline $\begin{array}{l}\text { Received: 03/03/2020 } \\
\text { Accepted: 28/03/2020 } \\
\text { Published: } 31 / 03 / 2020 \\
\text { Volume: } 3 \\
\text { Issue: } 1 \\
\text { DOI: } \\
\text { https://doi.org/10.33019 } \\
\text { /berumpun.v2i2.27 } \\
\text { KEYWORDS } \\
\text { Psychological Subject, } \\
\text { Unmarked Theme, } \\
\text { Marked Theme, Nominal } \\
\text { Group, Adverbial Group, } \\
\text { and Prepositional Phrase }\end{array}$ & $\begin{array}{l}\text { This research discusses one of the types of subjects functioning as a } \\
\text { theme proposed by Halliday (1985) in the English Declarative Clause } \\
\text { which is called Psychological Subject. Halliday claims the } \\
\text { interpretation of Psychological subject into as something which is the } \\
\text { concern of the message. It is the first constituent which becomes a } \\
\text { 'subject-matter' of the clause. The data are taken from two kinds of } \\
\text { books. The first one is an autobiography book and the second one is a } \\
\text { medical book. The aim of this research is to identify the kinds of theme } \\
\text { found in psychological subjects in the English Declarative Clause and } \\
\text { also categories found in psychological subjects functioning as theme. } \\
\text { The method used is a descriptive method and the technique employed } \\
\text { is paraphrasing. The descriptive method was used to depict the } \\
\text { empirical data discovered in those sources. Meanwhile, the } \\
\text { paraphrasing technique was employed in order to explore the } \\
\text { characteristics of psychological subject functioning as theme, types of } \\
\text { theme and categories of syntactic units. The study shows that } \\
\text { Psychological Subject (PS) functioning as a theme can be filled by } \\
\text { words and groups which could be realized by nominal groups (nouns } \\
\text { and pronouns), nominal group complexes, adverbial groups or } \\
\text { prepositional phrases. Nominal groups (nouns and pronouns) and } \\
\text { nominal group complexes can be identified as unmarked themes } \\
\text { which are the ordinary, expected, and usual form according to } \\
\text { Deterding (2001), Gerot and Wignel (1994) identified as the subject } \\
\text { of the sentence. Meanwhile, adverbial groups and prepositional } \\
\text { phrases could be identified as marked themes because they become } \\
\text { the first constituents which perform the point of the departure of the } \\
\text { message in the clause. }\end{array}$ \\
\hline
\end{tabular}

\section{Introduction}

It is generally recognized that many foreign language learners have difficulties in choosing or identifying the topic or subject being discussed in a text. It is very important because by knowing the topic we will know the important point being discussed in a text. Topic is what a text, section or clause is about and topic is always conceptualized as an entity or a nominalization (Downing and Locke, 2006)

The information above, however, is not necessarily associated with Theme. Theme and Topic are quite different types of category. We introduced the concept of theme when we are talking about textual meaning. Theme also is what the speaker or writer chooses as the point of departure for the message in any one clause or sentence. 
What we are saying about the theme is called Rheme (Halliday, 1985). They are sometimes realized by the same words or phrases as subject and predicate respectively.

(1). My little puppy sat on the chair. Theme Rheme Subject Predicate

By focusing on the concept about theme in the declarative clause, therefore the main discussion of this research will refer to a discussion of theme in the declarative clause. In a declarative clause, the typical pattern is one in which theme is conflated with Subject. Instead, various interpretations have grown around the subject notion which could be summarized as follows: (i) something which is the concern of the message or considered as a Psychological Subject, (ii) something which is being predicated or it is considered as a Grammatical Subject and (iii) the doer of the action or is considered as a Logical Subject.

By knowing the information above, the writer is interested in doing a research by applying and discussing the concept of theme with the term of one of three interpretations of subject notion according to Halliday which is called Psychological subject. Like illustrated by Halliday (1985), in My little puppy sat on the chair, it is reasonable to claim that My little puppy is, in fact, the psychological subject because my little puppy is the one with whom the message is concerned.

In line with the theory that was discovered by Halliday that the constituents that can fill the role of the psychological subject as a theme can be constituents of word and groups such as noun, pronoun, adverb, nominal group, adverbial group, preposition group and prepositional phrase. The position is always at the beginning of a clause because it is a point of departure. In textual message, the information conveyed at the beginning of a clause is an important point that someone wants to convey in textual analysis.

Guided by this concept, the writer begins to think of a research which focuses on what kinds of theme found in psychological subjects in the English Declarative Clause and also categories or word classes found in psychological subjects functioning as theme. The data were taken from two kinds of book. They are an autobiography book and a medical book.

The writer's study is based on Systemic Functional English Grammar as proposed by Halliday (1985), Bloor and Bloor (1996) and Miller (2002) supported by Downing and Locke (2006), Gerot and Wignell (1994) and Lock (1994). In Functional English Grammar, we are foregrounding the role of grammar as a resource for constructing meaning (Halliday, 1994). 


\section{LITERATURE REVIEW}

\subsection{Rank}

Bloor and Bloor (1995: 6) state that Hallidayan linguistics employs the notion of rank. In brief, this simply states that a sentence consists of one or more clauses; a clause consists of one or more groups; a group consists of one or more words; and a word consists of one or more morphemes. Each of these ranks refers to a unit of meaning. The examples in Fig. 2.1 provide illustrations of each rank from example of a clause (1) on the following page.

Fig. 2.1 Examples of rank

\begin{tabular}{lll}
\hline Sentence & $\begin{array}{l}\text { Recent research is shedding new light on how } \\
\text { acupuncture might work though we still have no definite } \\
\text { answers. }\end{array}$ \\
\hline Clause & $\begin{array}{l}\text { Recent research is shedding new light on how } \\
\text { acupuncture might work } \\
\text { (though) we still have no definite answers }\end{array}$ \\
\hline Group & $\begin{array}{l}\text { recent research } \\
\text { is shedding }\end{array}$ & - new light \\
& $\begin{array}{l}\text { Answers } \\
\text { still }\end{array}$ \\
\hline Word & $\begin{array}{l}\text { answer } \\
\text { Morphemite answers }\end{array}$ \\
\hline & -s shed [d] & -ing \\
\hline
\end{tabular}

This can be represented diagrammatically as in Fig. 2.2. This type of diagram is known as either a tree diagram, because it looks like an upside-down tree with a trunk and branches, or a constituency diagram, because it shows the constituents of the higher rank.

Constituency is concerned with the structural organization of the sentence or how the sentence is build up out of its various parts. As we can see from the tree diagram in Fig. 3.2, the clause is a constituent unit of a sentence. Similarly, in Fig. 3.3 a group is a constituent unit of a clause, and a word is a constituent unit of a group. In functional grammar, constituency is closely related to the principle of the rank scale. 2

Fig. 2.2 Sentence Constituency Sentence

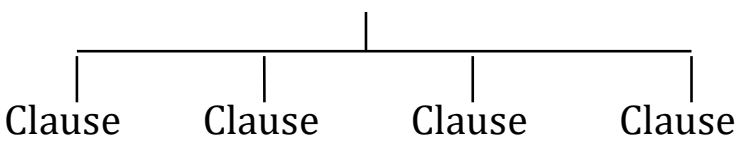


Fig. 2.3 Constituency of a Clause

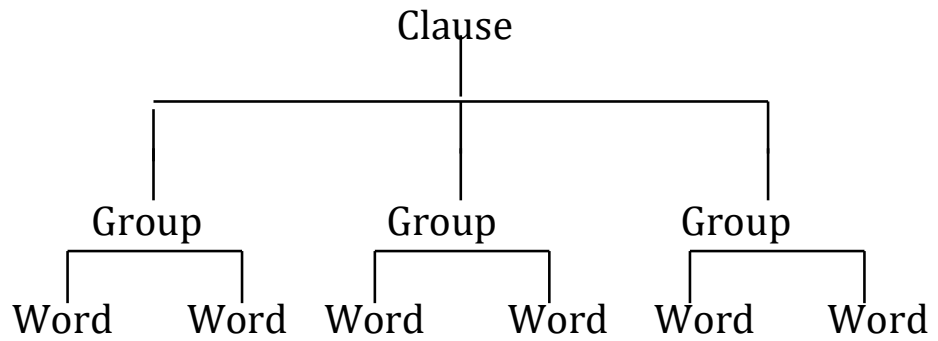

\subsection{Word Classes}

According to Bloor and Bloor (1996), one of the great contributions that the grammarians of ancient Greece and Rome made to our understanding of language was the development of a set of categories for classifying words. These categories came to be known in English as parts of speech. These are usually recognized as noun, verb, adjective, adverb, pronoun, preposition, conjunction, article and/or interjection.

Nowadays, among linguists the term parts of speech is not often used, and categories of this kind are called word classes. Like traditional grammar, Hallidayan grammar also features eight word classes, but they are not quite the same as the traditional ones. They are noun, adjective, numeral, determiner, verb, preposition, adverb and conjunction.

2) Soon a massive system was developed, consisting largely of numerous flood barriers, two dams and several branch canals.

The analysis of example (2) given in Fig. 2.4 (overleaf) reveals samples of all eight of Halliday's word classes.

Fig. 2.4 Samples of Halliday's Word Classes

\begin{tabular}{ll}
\hline Noun & system, flood, barriers, dams, branch, canals \\
\hline Adjective & Massive \\
\hline Numeral & numerous, two, several \\
\hline determiner & A \\
\hline Verb & was, developed, consisting \\
\hline preposition & Of \\
\hline Adverb & soon, largely \\
\hline conjunction & And \\
\hline
\end{tabular}


BERUMMUIN

International Journal of Social, Politics, and Humanities

https://berumpun.ubb.ac.id/index.php/BRP

a. Nouns

Some of these items can be subclassified, for example, nouns subdivided into common nouns, proper nouns and pronouns. These have qualities in common, hence their overall classification as noun, but they are also grammatically distinct from each other in some respects, and so there are distinguishing labels available, too.

3) Wedgwood experimented ceaselessly.

In example (3), Wedgwood belongs to a subclass of nouns known as proper nouns, which are traditionally described as the individual names of person (Abdullah, Picasso, Shakespeare), places (such as Sydney, Japan, Alberta), ships, trains and aeroplane, institutions and organization (such as Toyota, United Nations). In English they are normally written with a capital letter.

\section{b. Pronouns}

Consider the following example, written by the medieval Italian traveler, Marco Polo.

4) Let me add only that the Great Khan has no authority over them and they render no tribute or other acknowledgement. (Bloor and Bloor:1995)

Pronouns in this example are me, them and they. They are classed as a type of noun because they realize the same grammatical functions as common and proper nouns. In the example given, the pronoun $m e$ refers to the writer. If someone else told the story, me might be replaced by he or by Marco. Them and they refer to some third party, an already identified group of people.

There are various kinds of pronouns, including the personal pronoun in Fig. 2.5. The personal pronouns in the right-hand column can be distinguished from those to their left by the fact that they occur as modifiers of other nouns (for example, my book, her prize) whereas the ones on the left can 'stand alone' (mine referring to my book, hers to her prize, and so on, but without the common noun book or prize being mentioned).

Fig. 2.5 Personal Pronoun

\begin{tabular}{l|l|l}
\hline Singular & I, me, mine & My \\
\hline First person & you, yours & Your \\
\hline Second Person & he, him, his & His \\
\hline Third Person & she, her, hers & Her \\
\hline & it, its & Its \\
\hline \multicolumn{2}{|l}{} \\
\hline Plural & we, us, ours & Our \\
\hline First Person & you, yours & Your \\
\hline Second Person & they, them, theirs & Their \\
\hline Third Person &
\end{tabular}




\subsection{Groups}

Bloor and Bloor (1996: 26) also state that groups consist of:

\section{a. Nominal Group}

Not all nouns can stand alone in the way that proper nouns and many personal pronouns usually do. Nouns can also, of course, occur with more extensive modification. Consider example (5):

(5) A manager with a black coat read in his room.

Thus, in example (5), A manager with a black coat is a nominal group functioning as subject of the clause. According to the rank scale, a group is made up of one or more words and a clause is made up of one or more groups. The key grammatical item in the group is called the head. The remaining elements are modifiers. Thus, a nominal group is typically a group with a noun (or pronoun) as its head. For example, this microprocessor, is a nominal group with microprocessor is a head and this is as modifier.

\section{b. Verbal Group}

A verbal group may consist of simple verb; for example drives in example (6), is in (7). A verbal group may also be more complex, as with must submit in (8).

(6) The driver drives a car very fast.

(7) The Greater danger is that of flooding.

(8) All students must submit the assignment on time.

c. Adverbial Group

Adverbial group tends to have simpler structure than nominal or verbal groups. The adverbial group normally has an adverb as its head. Example (9) somewhat earlier is the adverbial group; earlier is the head and somewhat the modifier.

(9) Somewhat earlier the first application of glaze to pottery was made.

Following Bloor \& Bloor, Martin et al complete the opinion about adverbial group. They said that adverbial groups consist of one or more adverbs.

\section{d. Preposition Group}

A preposition group has a preposition as head and this is not often modified. Some preposition groups do contain modifiers, however; for instance: just inside has inside as head and just as modifier. Other examples are right on (as in right on target), slightly over (as in slightly over the edge), far beyond( in far beyond our expectations).

\section{e. Prepositional Phrase}

A preposition group always occurs with nominal group to make up a prepositional phrase; for example in the class is a prepositional phrase made up of a preposition in 


\section{https://berumpun.ubb.ac.id/index.php/BRP}

and a nominal group the class. In other words, a prepositional phrase consists of a preposition followed by nominal group.

Besides, Lock (1996) defines a prepositional phrase has a comparable structure, with a preposition (a word like to, from, behind, in, with, through, and about, or a complex preposition such as in front of, in spite of, and by means of) followed by a prepositional object.

\subsection{Psychological Subject}

According to Halliday (1985:33), a psychological subject refers to 'that which is the concern of the message. It was called 'psychological' because it was what the speaker had in his mind to start with, when embarking on the production of the clause. Chalker (1984: 16) assumes that a psychological subject is also the 'subject-matter' of the sentence that serves as the starting point for the predication.

Following Halliday, Miller (2002: 89) defines the term of psychological subject based on the example as follow:

(10) The dogs bite a cat.

(11) This key was found.

In (10), the dogs is a starting point of the message; it denotes the entities about which the speaker wishes to say something, as the traditional formula puts it. However, in (11) the psychological subject is this key because this key is a starting point of the message.

\subsection{Theme and Rheme}

Theme and Rheme are two terms which represent the way in which information is distributed in a sentence. The definition of Theme given by Halliday (1985:38) is that that Theme is given information serving as "the point of departure" of a message. The given information is the information which has already been mentioned somewhere in the text, what you-listener/reader-already know about, or access to. In other words, Theme typically contains familiar, old or given information. Theme provides the settings for the remainder of the sentence - Rheme. Rheme is the remainder of the message in a clause in which Theme is developed, that is to say, Rheme typically contains unfamiliar or new information. New information is knowledge that a writer assumes the reader does not know or what I-speaker/writer-am asking you listener/reader-to attend to.

As a general guide, we can say that the Theme can be identified as that element which comes up in the first position in the clause. The Theme is one element in a particular structural configuration which, taken as a whole, organizes the clauses as a message; this is the configuration Theme + Rheme. A message consists of a Theme combined with a Rheme. 
Fig 2.6 The Overview of Theme and Rheme

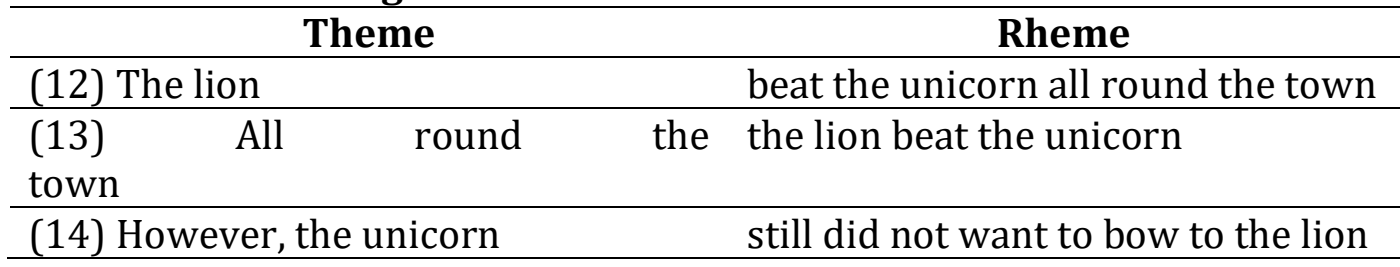

Following Halliday, Downing and Locke (2006: 223-224) also give a definition about Theme and Rheme. According to them, it is said that:

"Theme and Rheme are two components which together make up the organizational construct that is the thematic structure of the clause. The Theme comes first and is identified as the first constituent in the clause. What follows is the Rheme".

Looking at the clause as a unit of communication, we can say that Theme is the clause constituent which, whatever its syntactic function, is selected to be the point of departure of the clause as a message.

\subsection{Unmarked Theme and Marked Theme in Declarative Clauses} Before we proceed, we need to discuss the concept of Unmarked Theme and Marked Theme. An unmarked feature is the ordinary, expected, and usual form. Deterding (2001), Gerot and Wignell (1994) say that with reference to theme, in statements the theme usually the subject of the sentence. Following them, Downing and Locke (2006) say the same thing in relation to the unmarked theme. They say that the order of clause elements in unmarked theme has subject as Theme. They also explain that subject can be realized by various classes of groups and clauses such as: Nominal group, Nominal group complex or Nominal (embedded) Clauses.

A theme which is not the subject is called a marked theme. Gerot and Wignell (1994) also say that the term marked is used because it stands out. It attracts attention because it is not what we normally expect to find. Downing and Locke (2006) say that when theme is realized by a temporal or spatial adjunct it is a circumstantial theme which sets up a time-space frame within which the participant chain develops. The elements which can be categorized as marked themes are fronted Adverbial, Prepositional Phrase, or Complement.

Each of the following examples of three clauses has a different point of departure.

(15) Michelangelo finished the statue of David in 1504.

(16) The statue of David was finished by Michelangelo in 1504.

(17) In 1504 Michelangelo finished the statue of David.

In (15) and (16) the word order is unmarked and the theme is the subject. In other words, Michelangelo in (15) and The statue of David in (16) function simultaneously as subjects and as themes. Such themes are referred to as unmarked 


\section{https://berumpun.ubb.ac.id/index.php/BRP}

themes. Any themes other than the subject, for example In 1504 in (17), are therefore referred to as marked theme, although there are, of course, degrees of markedness.

\section{METHODOLOGY}

The method used is a descriptive method and the technique employed is paraphrasing. The descriptive method was used to depict the empirical data discovered in those sources. Meanwhile, the paraphrasing technique was employed in order to explore the characteristics of psychological subject functioning as theme, types of theme and categories of syntactic units.

The method and technique used by the writer in collecting data are as follows: first, the writer reads the data. The data are taken from two kinds of books. They are an autobiography book and a medical book. Then, the writer chooses the data by classifying the sentence into several indicators, such as: types of subject, the types of the theme, after knowing the themes of the clause the writer categorizes them into word, group, or phrase.

\section{RESULTS AND DISCUSSION}

\section{a. Unmarked Theme}

\section{Noun}

(DT. 95)

\begin{tabular}{ll}
\hline Violence & is carried out of the townships into the white living areas \\
\hline PS & \\
\hline Theme & Rheme \\
\hline
\end{tabular}

From the data (95) above, the first constituent functioning as a theme is filled by a noun, Violence, known as an unmarked theme. It is called an unmarked theme because the noun, Violence, is the subject of the clause and also performs a point of the departure of the message in a clause. The concept of a point of the departure can be interpreted as the clause's message that the speaker or the writer has selected as the jumping off point that is what the clause is "about". From this data, the clause could be glossed as something like "I am going to tell you about Violence, which is carried out of the townships into the white living areas".

The subject, Violence, could be considered as a psychological subject because it is the first constituent which becomes a 'subject-matter' of the clause. In other words, it is meant something that the message is concerned.

(DT. 184)

\begin{tabular}{ll}
\hline Maryann & went to her gynecologist for a routine checkup. \\
\hline PS & \\
\hline Theme & Rheme \\
\hline
\end{tabular}


Based on the data (184), the first constituent functioning as a theme is filled by a noun Maryann which is known as an unmarked theme. It is called by an unmarked theme because Maryann is a subject of the clause and becomes a point of the departure of the message. The concept of a point of the departure can be interpreted as a message appearing in a clause that the speaker or the writer has chosen as the jumping off point that is what the clause is "about". From this data, the clause could be glossed as something like "I am going to tell you all about someone, she is Maryann, a woman who went to her gynecologist for a routine checkup, not anyone else".

Maryann can be considered as a psychological subject because Maryann is a starting point of a 'subject-matter' of the clause. Therefore, Maryann is known as the one with whom the message is concerned.

(DT. 168)

\begin{tabular}{ll}
\hline Smokers & use cigarettes to enhance good feeling. \\
\hline PS & \\
\hline Theme & Rheme \\
\hline
\end{tabular}

Based on the data (168), the first constituent functioning as a theme is filled by a noun Smokers which is known as an unmarked theme. It is considered as an unmarked theme because Smokers is a subject of a clause and becomes a point of the departure of the message. The concept of a point of the departure can be interpreted as a message appearing in a clause that the speaker or the writer has selected as the point that is what the clause is "about". From this data, the clause could be glossed as something like "I am going to tell you about smokers, they use cigarettes to enhance good feeling".

The word Smokers can be considered as a psychological subject because the word Smokers is a starting point of a 'subject-matter' of the clause. Therefore, the word Smokers is known as the one with whom the message is concerned.

\section{Pronoun}

\section{(DT. 88)}

\begin{tabular}{ll}
\hline He & $\begin{array}{l}\text { is, in the words of his official biographer Anthony Sampson, ' a } \\
\text { universal hero'. }\end{array}$ \\
\hline PS & \\
\hline Theme & Rheme \\
\hline
\end{tabular}

From the data (88) above, the first constituent functioning as a theme is filled by a pronoun, $\mathrm{He}$, known as an unmarked theme. It is called an unmarked theme 
https://berumpun.ubb.ac.id/index.php/BRP

because pronoun $\mathrm{He}$ is a subject of the clause and also performs a point of the departure of the message in a clause. From this data, the clause could be glossed as something like "I am going to tell you that $\mathrm{He}$, someone who is, in the words of his official biographer Anthony Sampson, ' a universal hero'”.

From the explanation above, pronoun, $\mathrm{He}$, could be automatically called as a psychological subject. That is the first constituent which becomes a 'subject-matter' of the clause. In other words, it is meant something that the message is concerned.

\section{(DT. 98)}

\begin{tabular}{ll}
\hline I & turn now to my own position. \\
\hline PS & \\
\hline Theme & Rheme
\end{tabular}

From the data (98) above, the first constituent functioning as a theme is filled by a pronoun, $I$, known as an unmarked theme. It is considered as an unmarked theme because pronoun $I$ is the subject of the clause and also performs a point of the departure of the message in a clause. The concept of a point of the departure can be interpreted as the clause's message that the speaker or writer has selected as the jumping off point that is what the clause is "about". From this data, the clause could be glossed as something like "I am going to tell you that $I$, a person who turn now to my own position".

From the explanation above, pronoun, $I$, could be automatically assumed as a psychological subject. That is the first constituent which becomes a 'subject-matter' of the clause. In other words, it is meant something that the message is concerned.

\section{(DT. 162)}

\begin{tabular}{ll}
\hline We & $\begin{array}{l}\text { decided, therefore, in our preparations for the future, to } \\
\text { make provision for the possibility of guerrilla warfare. }\end{array}$ \\
\hline PS & Rheme \\
\hline Theme & Re
\end{tabular}

Based on the data (162), the first constituent functioning as a theme is filled by pronoun We which is known as an unmarked theme. It is considered as an unmarked theme because pronoun $W e$ is a subject of the clause and becomes a point of the departure of the message. The concept of a point of the departure can be interpreted as the clause's message that the speaker or the writer has chosen as the point that is what the clause is "about". From this data, the clause could be said as something like "I 


\section{https://berumpun.ubb.ac.id/index.php/BRP}

am going to inform you about people that are $W e$, who decided, therefore, in our preparations for the future, to make provision for the possibility of guerrilla warfare".

Besides, the theme We can be assumed as three different concepts of subject. They are the concepts of a psychological subject, a grammatical subject and a logical subject. Pronoun $W e$ can be considered as a psychological subject because pronoun We is a 'subject -matter' of the clause. In other words, pronoun $W e$ as a psychological subject here means the one with whom the message is concerned in the clause.

\section{Nominal Group}

(DT. 92)

\begin{tabular}{ll}
\hline Tobacco companies & $\begin{array}{l}\text { have been sued for failing to display even this warning } \\
\text { adequately. }\end{array}$ \\
\hline PS & \\
\hline Theme & Rheme \\
\hline
\end{tabular}

From the data (92) above, the first constituent functioning as a theme is filled by a nominal group, Tobacco Companies, known as an unmarked theme. It is considered as an unmarked theme because the nominal group, Tobacco companies, is a subject of the clause which is also a psychological subject. It performs a point of the departure of the message in a clause. The concept of a point of the departure can be interpreted as a message that the speaker or writer has selected as the jumping off point that is what the clause is "about". From this data, the clause could be glossed as something like "I am going to tell you about Tobacco companies, something which have been sued for failing to display even this warning adequately". (DT. 105)

\begin{tabular}{ll}
\hline $\begin{array}{l}\text { The American Cancer } \\
\text { Society }\end{array}$ & $\begin{array}{l}\text { has played an extremely active role in trying to } \\
\text { prevent smoking-caused cancers. }\end{array}$ \\
\hline PS & \\
\hline Theme & Rheme \\
\hline
\end{tabular}

According to the data (105), the first constituent functioning as a theme is filled by a nominal group The American Cancer Society which is known as an unmarked theme. It is considered as an unmarked theme because the nominal group, The American Cancer Society, is a subject of the clause and performs a point of the departure of the message in this clause. The concept of a point of the departure can be interpreted as a message that the speaker or the writer has selected as the jumping off point that is what the clause is "about". From this data, the clause could be glossed as something like The American Cancer Society, is one organization which has played an extremely active role in trying to prevent smoking-caused cancers. 
The nominal group, The American Cancer Society, can be considered as a psychological subject because it is a starting point of a 'subject-matter' of a clause. Therefore, it is something that the message is concerned.

(DT. 166)

The Programme of Action spawned the Defiance Campaign and head-on confrontation with the apartheid state.

\section{PS}

Theme Rheme

In accordance with the data (166), the first constituent functioning as a theme is filled by a nominal group, The Program of Action, known as an unmarked theme. It is considered as an unmarked theme because The Program of action is a subject of the clause performing the point of the departure of the clause. The concept of point of the departure can be interpreted as a message that the speaker or the writer has chosen as the jumping off point that is what the clause is "about". From this data, the clause could be glossed as something like "We are going to tell you about something, The Program of Action that spawned the Defiance Campaign and head-on confrontation with the apartheid state, not the other program".

It can be considered as a psychological subject because the nominal group, The Program of Action, is a 'subject-matter' of the clause. That is something that the message is concerned.

\section{Nominal Group Complexes}

(DT. 174)

\begin{tabular}{ll}
\hline Joe and Marie & $\begin{array}{l}\text { also learned some important lessons from their } \\
\text { experience with cancer. }\end{array}$ \\
\hline PS & Rheme \\
\hline Theme & \\
\hline In accordance with the data (174), the first constituent functioning as a theme is
\end{tabular}
filled by a nominal group complex, Joe and Marie, which is known as an unmarked theme. It is considered as an unmarked theme because Joe and Marie are a subject of a clause and performs a point of the departure of the clause. The concept of a point of the departure can be interpreted as a message appearing in a clause that the speaker or the writer has chosen as the point that is what the clause is "about". From this data, the clause could be glossed as something like "I am going to tell you about two people, they are Joe and Marie who learned some important lessons from their experience with cancer".

Joe and Marie should be considered as a psychological subject because the nominal group complex, Joe and Marie, is a 'subject-matter' of the clause. It is meant as something that the message is concerned. 
(DT.175)

\begin{tabular}{l}
\hline $\begin{array}{l}\text { Tuberculosis, pellagra, } \\
\text { kwashiorkor, gastroenteritis and } \\
\text { scurvy }\end{array}$ \\
\hline PS
\end{tabular}

Theme Rheme

In relation to data (175), the first constituent functioning as a theme is filled by a nominal group complex, Tuberculosis, pellagra, kwashiorkor, gastroenteritis and scurvy, that is known as an unmarked theme. It is considered as an unmarked theme because Tuberculosis, pellagra, kwashiorkor, gastroenteritis and scurvy become the subject of that clause or perform a point of the departure of the clause. The concept of a point of the departure can be interpreted as the clause's message that the speaker or the writer has chosen as the point that is what the clause is "about". From this data, the clause could be glossed as something like "I am going to tell you something about some diseases, they are Tuberculosis, pellagra, kwashiorkor, gastroenteritis and scurvy that bring death and destruction of health".

Tuberculosis, pellagra, kwashiorkor, gastroenteritis and scurvy could be considered as a psychological subject because Tuberculosis, pellagra, kwashiorkor, gastroenteritis and scurvy is a 'subject-matter' of the clause. That is something that the message is concerned in a clause.

\section{b. Marked Theme}

1. Adverb

(DT. 60)

\begin{tabular}{ll}
\hline Soon, & $\begin{array}{l}\text { we would achieve our central and all-defining goal of a } \\
\text { nonracial franchise based on a common voters' roll, the } \\
\text { key to all political transformation. }\end{array}$ \\
\hline PS & GS \\
& LS \\
\hline Theme & Rheme \\
\hline
\end{tabular}

The data (60) shows that the first constituent functioning as a theme is filled by an adverb Soon which categorized as a marked theme. It is considered as a marked theme because the adverb soon is not a subject of the clause. It stands out which attracts attention because it is not what we normally expect. In a normal case, soon will be placed at the end of the clause after verb or object. However, the position of Soon becomes a psychological subject which is a point of the departure of the message. It can be interpreted as the clause's message that the speaker or the writer has selected as the point that is what the clause is "about". From this data, the clause could be glossed as something like "I am going to tell you about the length of the time, that is 
https://berumpun.ubb.ac.id/index.php/BRP

soon, we would achieve our central and all-defining goal of a nonracial franchise based on a common voters' roll, the key to all political transformation."

(DT. 56)

\section{Now}

she examines her breast every month, gets a Pap smear

for servical cancer every six months and never misses a thorough annual checkup.

\begin{tabular}{ll}
\hline PS & GS \\
& LS
\end{tabular}

Theme Rheme

The data (56) shows that the first constituent functioning as a theme is filled by an adverb Now which is categorized as a marked theme. It is assumed as a marked theme because the adverb Now is not a subject of the clause. It stands out which attracts attention because it is not what we normally expect. In a normal case, Now will be placed at the end of the clause to show the time. However, the position of Now becomes a point of the departure of the message. The concept of a point of the departure can be interpreted as a message in a clause that the speaker or the writer has chosen as the point that is what the clause is "about". From this data, the clause could be glossed as something like "I am going to tell you about the time, that is Now, she examines her breast every month, gets a Pap smear for cervical cancer every six months and never misses a thorough annual checkup."

Because of this reason, the adverb, Now, could be identified as only a psychological subject. It happens because Now, is a 'subject-matter' of the clause which means something that the message is concerned.

(DT. 19)

\begin{tabular}{ll}
\hline Statistically & the incidence of cancer is formidable. \\
\hline PS & GS \\
\hline Theme & Rheme \\
\hline
\end{tabular}

Data (19) shows that the first constituent functioning as a theme is filled by an adverb Statistically which is categorized as a marked theme. It is considered as a marked theme because the adverb Statistically is not a subject of the clause. It stands out which attracts attention because it is not what we normally expect. In a normal case, statistically will be placed at the end of the clause to modify verb. However, the position of Statistically becomes a point of the departure of the message. The concept of a point of the departure can be assumed as a message appearing in a clause that the speaker or writer has selected as the point that is what the clause is "about". From this data, the clause could be glossed as something like "I am going to tell you something according to statistic (statistically), that the incidence of cancer is formidable." 
Because of this reason, the adverb, Statistically, could be identified as only a psychological subject. It happens because Statistically, is a 'subject-matter' of the clause which means something that the message is concerned.

\section{Adverbial Groups}

(DT. 40)

\begin{tabular}{ll}
\hline $\begin{array}{l}\text { The last three } \\
\text { decades }\end{array}$ & $\begin{array}{l}\text { women wore opaque stockings or long dresses, } \\
\text { protecting their legs from sunlight. }\end{array}$ \\
\hline PS & GS \\
& LS \\
\hline Theme & Rheme \\
\hline
\end{tabular}

From data (40) above, the first constituent functioning as a theme is filled by an adverbial group The last three decades which is categorized as a marked theme. It is considered as a marked theme because the adverbial group The last three decades is not a subject of the clause. It stands out which attracts attention because it is not what we normally expect. In a normal case, The last three decades $y$ will be placed at the end of the clause to show time. However, the position of The last three decades becomes a point of the departure of the message. The concept of a point of the departure can be interpreted as the message that the speaker or the writer has selected as the jumping off point that is what the clause is "about". From this data, the clause could be glossed as something like "I am going to tell you about the specific time, that is The last three decades, women wore opaque stockings or long dresses, protecting their legs from sunlight."

Because of this reason, the adverbial group, The last three decades, could be identified as only a psychological subject. It happens because The last three decades, is a 'subject-matter' of the clause which means something that the message is concerned.

(DT. 9)

\begin{tabular}{ll}
\hline $\begin{array}{l}\text { Twenty-five years } \\
\text { later }\end{array}$ & $\begin{array}{l}\text { Jonathan was found to have thyroid cancer as a result } \\
\text { of the radiation treatments during his first year of life. }\end{array}$ \\
\hline PS & GS \\
\hline Theme & Rheme
\end{tabular}

From data (9) above, the first constituent functioning as a theme is filled by an adverbial group Twenty-five years later which is categorized as a marked theme. It is considered as a marked theme because the adverbial group Twenty-five years later is not a subject of the clause. It stands out which attracts attention because it is not what we normally expect. In a normal case, Twenty-five years later will be placed at the end of the clause to show time. However, the position of Twenty-five years later becomes a 


\section{https://berumpun.ubb.ac.id/index.php/BRP}

point of the departure of the message. The concept of a point of the departure can be interpreted as the message that the speaker or the writer has selected as the jumping off point that is what the clause is "about". From this data, the clause could be glossed as something like "I am going to tell you about the specific time, that is Twenty-five years later, Jonathan was found to have thyroid cancer as a result of the radiation treatments during his first year of life."

Because of this reason, the adverbial group, Twenty-five years later, could be identified as only a psychological subject. It happens because Twenty-five years later, is a 'subject-matter' of the clause which means something that the message is concerned.

\section{Prepositional Phrase}

(DT. 29)

\begin{tabular}{ll}
\hline After some research & we proposed Genadendal (Valley of Mercy). \\
\hline PS & GS \\
& LS \\
\hline Theme & Rheme \\
\hline
\end{tabular}

In accordance with data (29) above, the first constituent functioning as a theme is filled by a prepositional phrase After some research which is categorized as a marked theme. It is considered as a marked theme because the prepositional phrase After some research is not a subject of the clause. It stands out which attracts attention because it is not what we normally expect. In a normal case, After some research will be placed at the end of the clause to show time. However, the position of After some research becomes a point of the departure of the message. The concept of a point of the departure can be interpreted as the message in a clause that the speaker or the writer has selected as the point that is what the clause is "about". From this data, the clause could be glossed as something like "I am going to tell you about the specific time that is After some research, we proposed Genadendal (Valley of Mercy)."

The prepositional phrase, After some research, could be identified as a psychological subject. It happens because After some research, is a 'subject-matter' of the clause which means something that the message is concerned.

DT. 69

\begin{tabular}{ll}
\hline $\begin{array}{l}\text { To the readers of } \\
\text { this book }\end{array}$ & we want to welcome you to the celebration. \\
\hline PS & GS \\
& LS \\
\hline Theme & Rheme \\
\hline
\end{tabular}

In accordance with data (69) above, the first constituent functioning as a theme is filled by a prepositional phrase To the readers of this book which is categorized as a 
BERUMPUN

International Journal of Social, Politics, and Humanities

https://berumpun.ubb.ac.id/index.php/BRP

marked theme. It is considered as a marked theme because the prepositional phrase To the readers of this book is not a subject of the clause. It stands out which attracts attention because it is not what we normally expect. In normal case, To the readers of this book will be placed at the end of the clause as an object preposition. However, the position of To the readers of this book becomes the point of the departure of the message. The concept of a point of the departure can be interpreted as the message in a clause that the speaker or the writer has selected as the jumping off point that is what the clause is "about". From this data, the clause could be glossed as something like "I am going to tell you that To the readers of this book, we want to welcome you to the celebration". Because of this reason, the prepositional phrase, To the readers of this book, could be identified as only a psychological subject. It happens because To the readers of this book, is a 'subject-matter' of the clause which means something that the message is concerned.

\section{CONCLUSION}

From the analysis above it can be concluded that Psychological Subject (PS) can be filled by unmarked themes and marked themes. The unmarked themes are realized by nominal groups (noun and pronouns) and nominal group complexes. The marked themes are realized by adverbial groups and prepositional phrases. Adverbial groups and prepositional phrases could be termed as marked themes because they could be the first constituents which perform the point of the departure of the message in a clause.

The term of psychological subject refers to 'that which is the concern of the message. It was called 'psychological' because it was what the speaker had in his mind to start with, when embarking on the production of the clause. A psychological subject is also the 'subject-matter' of the sentence that serves as the starting point for the predication. There is an interrelated correlation between psychological subject and theme. That is, their positions are the same as occupying the position at the beginning of a sentence or clause. In addition, they are both "subject-matter' of the information to be conveyed in understanding the message of the text.

\section{About the Authors}

The first author is Puspita Sari, S.S., M.Hum. She was born in Cirebon on $22^{\text {nd }}$ of November 197. She is an English lecturer of Widyatama University of Bandung of Indonesia. She graduated from Master Degree of English Linguistics Program Universitas Padjadjaran in 2009. She has been actively teaching since 2002-Now and has published some research articles in nasional and international journals for recent five years. Some of them are scopus indexed. Her research interests are about linguistics issues, applied linguistics such as teaching English and classroom-action 
BERUMPUN

International Journal of Social, Politics, and Humanities

https://berumpun.ubb.ac.id/index.php/BRP

research. Some trainings have been accomplished a few years ago, one of them is On line Course Training organized by Oregon University of USA in 2011: English for Specific Purposes, Best Practice. It was equivalent to 5 Continuing Education Units (CEUs) or 50 hours of Instruction. She is also active becoming a member of ESAI (English Study Association of Indonesia), AISEE (The Association of The Indonesian Scholars of English Education) and ALTI (Asosiasi Linguistik Terapan Indonesia). The second author is Dr. Diana Anggraeni, M.Hum. She was born in Bandung August 19th 1968. She completed her education from Elementary school until Doctorate Program in Bandung. She graduated from Doctorate Program of Linguistics from Universitas Padjadjaran Bandung on July, 23 ${ }^{\text {rd }}, 2018$. She has been working at the University of Bangka Belitung as a lecturer from 2006-now and currently serves as a Chair of Department of English Literature at the Faculty of Social and Political Sciences. She is actively as a member of ESAI. Her research interest is in the field of Linguistics. There are several journals that have been published. Her research in 2007 was funded by the Directorate of Higher Education and in 2018 she got Community Services Grant from The Ministry of Research, Technology and Higher Education.

\section{REFERENCES}

Bloor, T. \& Meriel, B. (1995). The Functional Analysis of English. New York: Oxford University Press.

Butt, D. et el (1994). Using Functional Grammar. Sydney: Macquarie University.

Chalker, S. (1984). Current English Grammar. Hongkong: Macmillan

Downing, A. \& Philip, L. (2006). English Grammar: A University Course. USA and Canada: Routledge.

Deterding, D. H \& Poedjosodarmo, G. R. (2001). The Grammar of English. Singapore: Prentice Hall

Freddi, M. (2004). Functional Grammar: An Introduction for the EFL Student. London: London Press.

Gerot, L. \& Peter W. (1994). Making Sense of Functional Grammar. Australia: Antipodean Educational Enterpress.

Halliday., M.A.K., (1985). An Introduction to Functional Grammar. London: The Chauser

Halliday., M.A.K., \& Hasan, R. (1994). Cohesion in English. London: Longman.

Jacobs, Rodeick A (1995). English Syntax: A Grammar for English Language Professionals. New York: Oxford University Press. 
Djajasudarma, Prof. Dr. (2006). Metode Linguistik: Ancangan Metode Penelitian dan Kajian. Bandung: Aditama.

Klammer et el. (2000). Analyzing English Grammar. USA: A Pearson Education Company.

Lipson, M. (2004). Exploring Functional Grammar. Function Grammar Studies. London: London Press.

Lock, G. (1996). Functional English Grammar: An Introduction for Second Language Teachers. New York: Cambridge University Press.

Martin, J.R, et el (1997). Working with Functional Grammar. New York: St. Martin Press.

Miller, J. (2002). An Introduction to English Syntax. Edinburg: Edinburg University Press.

Quirk, R., S. G., Leech, G. \& Svartvik, J. (1985). A Comprehensive Grammar of English. London: Longman.

Sujatna, E. T. S. (2008). Tata Bahasa Fungsional. Bandung: Uvula Press

\section{Journal on-line:}

Vallauri, E. L. 1995. A Simple Test for Theme and Rheme in the Clause Complex.Vol.17, No. 4: 357-378.

Fetzer, A. 2008. Theme Zones in English Media Discourse: Forms and Functions. Institute of English Studies, Leuphana University of Lueneburg, Scharnhorststr. 1, D-213. Lueneburg, Germany.

\section{Website:}

http://www.ling.helsinki.fi/kit/2004s/ctl310gen/GW-MSc Thesis/node16.html http://en.wikipedia.org/wiki/Subject_(grammar) 